\begin{tabular}{|l|l|l||}
\hline \multicolumn{2}{|c|}{ PublisherInfo } \\
\hline \hline PublisherName & $:$ & BioMed Central \\
\hline \hline PublisherLocation & $:$ & London \\
\hline \hline PublisherImprintName & $:$ & BioMed Central \\
\hline \hline
\end{tabular}

\title{
An emerging pattern
}

\begin{tabular}{|l|l|l||}
\hline \multicolumn{2}{|c|}{ ArticleInfo } \\
\hline \hline ArticleID & $:$ & 4025 \\
\hline \hline ArticleDOI & $:$ & $10.1186 /$ gb-spotlight-20010323-02 \\
\hline \hline ArticleCitationID & $:$ & spotlight-20010323-02 \\
\hline \hline ArticleSequenceNumber & $:$ & 96 \\
\hline \hline ArticleCategory & $:$ & Research news \\
\hline \hline ArticleFirstPage & $:$ & 1 \\
\hline \hline ArticleLastPage & $:$ & 3 \\
\hline \hline & & RegistrationDate : 2001-03-23 \\
ArticleHistory & $:$ & OnlineDate \\
\hline \hline ArticleCopyright & $:$ & BioMed Central Ltd2001 -03-23 \\
\hline \hline ArticleGrants & $:$ & \\
\hline \hline ArticleContext & $:$ & 130592211 \\
\hline \hline
\end{tabular}




\section{Kenneth Lee}

Email: kenlee_fr@yahoo.fr

During development, organizing centres at key locations in the embryo secrete morphogens that become distributed in a concentration gradient. It is thought that cells along the gradient adopt different fates depending on the concentration of the morphogen they encounter. In the 22 March Nature, three studies shed light on the elaborate regulation of some potent morphogens - members of the bone morphogenetic protein (BMP) family.

All three studies focus on the role of the Twisted gastrulation (Tsg) protein and find that, in both vertebrates and invertebrates, this protein binds to members of the BMP family, preventing them from signalling. The authors - Jeffrey Ross of the University of Minnesota and co-workers, Ian Scott of the University of Wisconsin Medical School and co-workers, and Chenbei Chang of Rockefeller University and colleagues - studied Tsg function in Drosophila (Nature 2001, 410:479-483), Xenopus (Nature 2001, 410:475-478) and the zebrafish (Nature 2001, 410:483-487), respectively.

Their findings lead to the following model of BMP regulation. In Drosophila, Decapentaplegic (Dpp), a BMP family member, forms a complex with Tsg and with a second inhibitor, Short gastrulation (Sog). The levels of Dpp are controlled by local production of Sog. When Sog is proteolytically degraded, Dpp is released in its active form. Tsg increases the binding of Dpp to Sog but also accelerates the degradation of Sog when the protease is present. In regions of the embryo where levels of Sog are high, degradation of Sog has little effect because there is plenty more Sog around to form a complex with Dpp and Tsg. In areas where Sog is scarce, Dpp is released. These interactions also occur in vertebrates, where Chordin - a relative of Sog - binds to Tsg and BMP4, a relative of Dpp.

\section{References}

1. University of Minnesota, [http://www.umn.edu/]

2. University of Wisconsin Medical School, [http://www.medsch.wisc.edu/]

3. The Rockefeller University, [http://www.rockefeller.edu/]

4. Ross JJ, Shimmi O, Vilmos P, et al: Twisted gastrulation is a conserved extracellular BMP antagonist. Nature 2001, 410:479-483., [http://www.nature.com/nature/] 
5. Scott IC, Blitz IL, Pappano WN, et al: Homologues of Twisted gastrulation are extracellular cofactors in antagonism of BMP signalling. Nature 2001, 410:475-478., [http://www.nature.com/ nature/]

6. Chang C, Holtzman DA, Chau S, et al: Twisted gastrulation can function as a BMP antagonist. Nature 2001, 410:483-487., [http://www.nature.com/nature/]

This PDF file was created after publication. 